FEDERAL RESERVE BANK OF SAN FRANCISCO

WORKING PAPER SERIES

\title{
The Road of Federal Infrastructure Spending Passes Through the States
}

\author{
Sylvain Leduc and Daniel Wilson \\ Federal Reserve Bank of San Francisco \\ February 2022 \\ Working Paper 2022-03 \\ https://www.frbsf.org/economic-research/publications/working-papers/2022/03/
}

\section{Suggested citation:}

Leduc, Sylvain, Daniel Wilson. 2022 "The Road of Federal Infrastructure Spending Passes Through the States," Federal Reserve Bank of San Francisco Working Paper 2022-03. https://doi.org/10.24148/wp2022-03

The views in this paper are solely the responsibility of the authors and should not be interpreted as reflecting the views of the Federal Reserve Bank of San Francisco or the Board of Governors of the Federal Reserve System. 


\title{
The Road of Federal Infrastructure Spending Passes Through the States
}

\author{
Sylvain Leduc and Daniel Wilson (FRB San Francisco)*
}

February 1, 2022

\begin{abstract}
Because federal infrastructure spending largely takes the form of grants to state governments, the macroeconomic impact of such packages depends on the share of federal grants that "passes through" to actual infrastructure spending done by states. A low degree of pass-through would tend to mute the economic impact from federal grants, reflecting a crowd-out effect on state spending. We first revisit Knight's (2002) influential finding of near-zero pass-through (perfect crowd out) of federal highway grants. That result is found to be specification-sensitive and is reversed completely in a longer sample, with estimates implying dollar-for-dollar pass-through of grants to spending. We then extend the analysis to allow for dynamics. We find a contemporaneous pass-through effect of about 1 and a longer-run cumulative effect of around 1.3. In the parlance of public finance, the flypaper effect is strong.
\end{abstract}

JEL Codes: H77, H54, E62

\footnotetext{
* We thank Brian Knight for generously providing his data and Sam Tarasewicz for excellent research. We benefited from useful discussions with Oscar Jordà, Kevin Lansing, and Nora Traum. The views expressed in this paper are solely the responsibility of the authors and should not be interpreted as reflecting the views of the Federal Reserve Bank of San Francisco, or of any other person associated with the Federal Reserve System.
} 


\section{Introduction}

In November 2021, President Biden signed into law the Infrastructure Investment and Jobs Act, which included authorization of over half a trillion dollars in new infrastructure spending. It also included roughly half a trillion dollars in reauthorization of existing infrastructure programs. Spread over a 10-year period, the bill is expected to boost potential output and productivity (Congressional Budget Office, 2021). However, because a large portion of federal infrastructure spending takes the form of grants to state governments, its macroeconomic impact largely depends on the share of federal grants that passes through to actual state infrastructure spending. Just as the macroeconomic impact of federal transfers to households depends on their marginal propensity to spend out of transfer income, the macroeconomic impact of federal grants to states depends on state governments' marginal propensity to spend out of grant revenue, an effect we refer to as pass-through. A low degree of pass-through—or, alternatively, a high degree of crowd-out of states' own funding - would thus mute the intended impact of the increase in federal infrastructure spending. ${ }^{1}$

A large literature initially documented the absence of crowd-out even for large unrestricted federal grants, which led Arthur Okun to dub this phenomenon the flypaper effect, since funding from the federal government tended to stick where it hit. ${ }^{2}$ However, a number of influential papers have challenged this finding, arguing that previous results were biased. One particularly prominent study is Knight (2002), who contends that the absence of crowd out is partly due to a failure to control for the endogeneity of grant revenue. ${ }^{3}$ In the context of highway grants, he argues that states in which voters value public goods the most may be more successful at lobbying the federal government for federal grants. As a result, a spurious positive correlation would arise between state spending on highways and federal highway grants. Knight proposed accounting for this endogeneity by using various measures of states' political influence in Congress as instruments for grants; he found that federal highway grants crowd out state spending nearly dollar for dollar. In

\footnotetext{
${ }^{1}$ Unlike households, which must either spend or save fiscal transfers, subnational governments receiving federal transfers intended for a specific type of spending, like infrastructure, have additional options for using the funds. In addition to spending the funds on infrastructure or saving them (e.g., adding to rainy-day funds), they could spend the funds on other purposes or pass the revenue on to taxpayers in the form of reduced tax rates, each of which could have separate macroeconomic impacts.

${ }^{2}$ See Hines and Thaler (1995) and Inman (2008) for surveys of the literature on the flypaper effect and Leduc and Wilson (2017) for a brief review of recent findings.

${ }^{3}$ As an example of the influence of the results in Knight (2002), the Congressional Budget Office (CBO) uses higher crowd-out estimates to assess the likely impact of federal grants on the economy (see, e.g., CBO 2016).
} 
other words, he finds the pass-through effect of federal highway grants is zero. ${ }^{4,5}$ More recently, Leduc and Wilson (2017) examined the federal highway grants included in the 2009 American Recovery and Reinvestment Act (ARRA), finding close to full pass-through in the first year and greater than full pass-through after several years. Yet, the ARRA grants and the Great Recession episode were somewhat unique, so those results may not be representative of the typical degree of pass-through for federal highway grants.

In this paper, we revisit the pass-through effect of federal highway grants, the largest category in the current infrastructure package, by extending Knight's (2002) study in several key dimensions. We first reproduce Knight's (2002) finding of zero pass-through over the period 1983-1997 using current vintages of data. We then show that this pass-through estimate increases substantially simply by adding time (year) fixed effects to the regression. In this case, one additional dollar of grant revenue increases state highway spending by 54 cents. The inclusion of time fixed effects is now standard in panel data analyses and controls for national factors, such as the business cycle and federal fiscal policies, which affect both state highway spending and federal highway funding. We next document that the degree of pass-through rises substantially, to at least 1, as more data are included in the analysis. In fact, simply expanding Knight's original sample period from 1983-1997 to 1983-2018 causes the pass-through coefficient to rise from 0.54 to $1.61 .^{6}$

One concern with Knight's original analysis is that the political instruments were quite weak predictors of state's federal highway grant revenue, potentially leading to weak instrument bias. Hence, in our analysis we also consider alternative instruments, exploiting the formula-based mechanism by which nearly all federal highway funds are apportioned to state governments (as opposed to funds earmarked for certain projects, which may be subject to political influence). Because the state-specific factors entering the apportionment formulas are often largely unrelated to current state economic conditions and also lagged several years, the formula-based distribution of federal highway grants provides an exogenous source of highway funding to states, independent

\footnotetext{
${ }^{4}$ For the remainder of the paper, we generally refer to the pass-through effect of grants, which is one minus the crowd-out effect.

${ }^{5}$ There also is a large empirical literature estimating the degree of pass-through for other (non-highway) types of federal grants, with mixed results. For instance, Duggan (2000), Gordon (2004), and Lutz (2010) find a low degree of pass-through, while Baicker (2001), Hoxby (2001), Card and Payne (2002), and Singhal (2008) find nearly full pass-through.

${ }^{6}$ See also CBO (2021) for much higher recent pass-through estimates.
} 
of states' own current economic conditions. ${ }^{7}$ When using apportionments in our instrumental variable (IV) approach, we find a contemporaneous pass-through effect of roughly 1.

Lastly, we extend Knight's (2002) analysis and the flypaper literature in general by considering dynamic effects. For the most part, this literature has focused solely on contemporaneous effects, abstracting from the possibility that it takes more than one year for state spending to fully respond to a shock in federal grants that year. We show that these dynamic effects are important. Following the approach Ramey and Zubairy (2018) used to calculate cumulative fiscal multipliers, we show that the cumulative pass-through of highway grants is around 1.3 over a six-year horizon, suggesting some crowding-in effects. ${ }^{8}$ We show that this response is heterogeneous with respect to state savings, with states with high savings having higher cumulative pass-through, possibly because they have less pressure to divert such funding to other uses. By contrast, we find no heterogeneity in pass-through effects with respect to the national business cycle.

\section{A General Specification}

We consider a general framework that nests Knight's (2002) static specification, while also allowing us to calculate cumulative effects of federal highway grants on state highway spending over time. As we show below, this is an important dimension to examine because federal grants to states tend to be highly persistent and the response of state spending may play out over more than one year. To capture these dynamic effects, we adopt an approach similar to that used by Ramey and Zubairy (2018) to calculate cumulative fiscal multipliers. Thus, we consider a general specification that encompasses both the contemporaneous and cumulative effects of a federal highway grant shock, shock ${ }_{s, t}$, on state highway spending:

$$
\sum_{j=0}^{h} G_{s, t+j}=\beta^{h} \sum_{j=0}^{h} F_{s, t+j}+\sum_{\tau=1}^{3} \rho_{\tau}^{h} G_{s, t-\tau}+\sum_{\tau=1}^{3} \psi_{\tau}^{h} F_{s, t-\tau}+\gamma_{h}^{\prime} X_{s, t}+\delta_{t}^{h}+\alpha_{s}^{h}+\varphi_{s}^{h} t+v_{s, t+h}
$$

\footnotetext{
${ }^{7}$ As Knight pointed out, the formulas used to apportion federal highway grants to states could still a priori be influenced by states' political power. However, the formulas to apportion highway grants have changed little over time, suggesting that apportionments have not been influenced much by changes in state political power.

${ }^{8}$ In Leduc and Wilson (2017) we documented substantial dynamic effects for the federal highway grants in the American Recovery and Reinvestment Act of 2009. Instead of leading to a crowding-out effect, we showed that \$1 in ARRA highway grants led states to spend, on average, roughly \$2 on highways, between 2009 and 2011.
} 
where $G_{s, t}$ is real highway spending (per capita) in state $s$ at time $t, F_{s, t}$ is real federal highway grants (per capita) received by the state and $v_{s, t}$ is an error term. The regression controls for a set of potential highway spending demand variables, $X_{s, t}$, and three lags each of the dependent variable and of federal grants. Following Knight (2002), we include in $X_{s, t}$ income per capita, population, drivers per capita, vehicles per capita, and three political controls: state House composition (percent Democrats), state Senate composition, and an indicator for having a Democrat governor. This general specification includes state and time fixed effects. In some cases, we also include state-specific time trends $\left(\varphi_{s}^{h} t\right)$.

The variable $h$ indicates the horizon over which the effects of federal grants on state highway spending are cumulated. For $h=0$, we obtain an estimate, $\hat{\beta}^{0}$, of the degree of contemporaneous pass-through. As $h$ increases, we obtain the estimated cumulative effects over longer horizons, $\hat{\beta}^{h}$. Following Ramey and Zubairy's approach to estimating the cumulative fiscal multiplier, the cumulative pass-through effect for any horizon can be obtained by estimating equation (1) via instrumental variables, using $\operatorname{shock}_{s, t}$, as an instrument for cumulative grants, $\sum_{j=0}^{h} F_{s, t+j}$. If federal highway grants are exogenous (orthogonal to $v_{s, t+h}$ ), then $\operatorname{shock}_{s, t}$ is simply year $t$ grants, $F_{s, t}$. If federal highway grants are endogenous, then shock $k_{s, t}$ can be measured using one or more exogenous instruments that should be predictive of year $t$ grants and, thus in turn, predictive of $\sum_{j=0}^{h} F_{s, t+j}$. This single-equation IV estimation is equivalent to taking the integral of the estimated impulse response function (IRF) of state highway spending with respect to the highway grants shock and dividing by the integral of the estimated IRF of highway grants with respect to the highway grants shock.

To provide a benchmark for our results, we start our analysis by estimating Knight's (2002) specification, which amounts to setting $h=0$ and $\rho_{\tau}^{h}=\psi_{\tau}^{h}=0$, and excluding time fixed effects $\left(\delta_{t}^{h}=0\right)$ and state-specific time trends $\left(\varphi_{s}^{h}=0\right)$ :

$$
G_{s, t}=\beta^{0} F_{s, t}+\gamma_{h}^{\prime} X_{s, t}+\alpha_{s}^{h}+v_{s, t}
$$

Motivated by the concern that federal grants received by a state may reflect the state's preferences for public goods, which would also influence state spending, Knight instrumented for 
grants using variables reflecting the state's political power in Congress. For instance, Knight considers state representatives on congressional transportation committees as one political instrument, since they could use their positions to tilt the apportionment of highway grants toward their state. Knight also includes the proportion of state congressional representatives in the majority party and their average tenure. Exogenous variations in states' political power at the federal level would then allow for a causal interpretation between state highway grants and state highway spending. Combining the state representations to the U.S. House of Representatives and the Senate yields the six political instruments used.

To examine the robustness of Knight's findings, we also consider an alternative instrument based on the procedure used to apportion federal highway funds to states in a series of grant programs collectively known as the Federal-Aid Highway Program (FAHP). For instance, the FAHP includes programs such as Interstate Maintenance (IM), National Highway System, and Surface Transportation Program, among others, covering various aspects of the highway system (see Leduc and Wilson (2013) for additional details about the FAHP). Periodically, Congress enacts multiyear legislation that authorizes spending on these programs. Since 1990, Congress has adopted six such acts. ${ }^{9}$ Importantly for our identification procedure, the state apportionments of federal highways funds are calculated from infrequently changed formulas based on state highway variables that are lagged three years, reflecting delays in compiling the data. For instance, the IM program apportioned funds under the 2005 SAFETEA-LU according to each state's share of national interstate lane-miles, its share of vehicle-miles traveled on interstate highways, and its share of payments into the Highway Trust Fund (HTF) with equal weights on each factor and with these factors entering the formulas with a three-year lag. Similar procedures are used to apportion funds for the other programs under the FAHP. In Leduc and Wilson (2017), we used two factors from the IM program formula (i.e., the share of interstate lane miles and HTF contributions) as representative instruments for all the FAHP programs. ${ }^{10}$ However, using the actual apportioned

\footnotetext{
${ }^{9}$ The Intermodal Surface Transportation Efficiency Act (ISTEA) in 1991 covered fiscal years (FY) 1992 through 1997; the Transportation Equity Act for the 21st Century (TEA-21) in 1998 covered FY1998-2003; the Safe, Accountable, Flexible, Efficient Transportation Equity Act: A Legacy for Users (SAFETEA-LU) in 2005 covered FY2005 - 2009; the Moving Ahead for Progress in the 21st Century (MAP-21) in 2012 covered FY2013 - 2014; and the Fixing America's Surface Transportation (FAST) Act in 2015 covered FY2016 - 2020.

${ }^{10}$ Using the full set of road factors used from the different formulas does not yield much additional first-stage power because they tend to be highly correlated.
} 
funds (implicitly derived from the formulas) works equally well, which is the approach we use below for simplicity.

\section{Static Results}

We start by estimating Knight's (2002) specification using his original data from 1983 to 1997. We then examine the impact of using alternative measures for some of the variables in the regression, in addition to including time fixed effects and updating the data sample to recent years. Appendix I provides details on all the data used in the analysis. In contrast to Knight, we use the IV/GMM estimator rather than 2SLS since it has the advantage of being heteroskedasticityconsistent. The results of estimating Knight's specification via IV/GMM and using Knight's data are shown in column (1) of Table 1. The coefficient on federal highway grants is essentially zero, consistent with what Knight (2002) reported. ${ }^{11}$

Having replicated Knight's result, we then estimate the same specification using an alternative data source for federal highway grants. Knight's data came from the Census Bureau's Survey of Government Finances, whereas we use highway grants data directly from the Federal Highway Administration (FHWA). While the two data sources are very highly correlated, we prefer the FHWA measure because it comes from the same source as the data on highway apportionments, which we use below as an instrument. The results are shown in column (2) and are very similar to those in column (1). In particular, like Knight, we obtain a coefficient on federal grants that is near zero and statistically insignificant. In column (3), we deflate monetary variables with a state-specific GDP deflator instead of the national GDP deflator used in Knight (2002). This deflator has the advantage of more accurately capturing changes over time in local costs of infrastructure projects. The coefficient on grants is now somewhat higher, but it remains statistically insignificantly different from zero.

In column (4), we add year fixed effects. Year fixed effects control not only for time trends but also for any unobserved national factors, like the national business cycle, that may affect both the instruments and state highway spending. Omitting such factors could bias the coefficient on grants. We find that controlling for such factors leads to a positive and significant coefficient on

\footnotetext{
${ }^{11}$ The coefficient we obtain using 2SLS is 0.1214 with a standard error of 0.4183 . Note that in Knight (2002), the dependent variable is measured as $\left(G_{i t}+F_{i t}\right)$ rather than just $G_{i t}$, so a flypaper effect of corresponds to a coefficient on of . Knight reported a coefficient of -0.8786 , which corresponds to a flypaper effect of 1 $0.8786=0.1214$.
} 
grants of about 0.53 . In other words, even with the same sample period, the same instruments, and the same conditioning variables used in Knight (2002), the result of a zero pass-through is overturned once time fixed effects are included.

In addition, Knight's (2002) data sample is relatively short, covering the period 1983 to 1997. In column (5), we extend this sample to 2018, the latest year for which we have data for the

congressional power instruments. The addition of 21 years of data has a meaningful impact on the results and increases the pass-through estimate even further to 1.56, indicating that a dollar of additional grants revenue boosts state highway spending by even more than a dollar.

However, one concern with Knight's political instruments is a weak first-stage. As shown in the table, the first-stage $F$-statistics for these instruments are generally low and below (or very close to) standard critical values associated with weak-instrument bias. Weak instruments also reduce precision, yielding higher standard errors. Therefore, we estimate the same model with time fixed effects and a longer sample, as in column (5), but replace the political instruments with current and three lags of FHWA apportionments, which as described earlier are themselves determined primarily by road factors through the FAHP formulas. As shown in column (6), these instruments yield a much stronger first-stage fit, with an $F$-statistic over 100, and smaller standard errors. In the second stage, we obtain a highly statistically significant pass-through estimate of 1.17, again showing that federal highway grants boost state highway spending a bit more than dollar for dollar.

Overall, Table 1 shows that Knight's (2002) result is highly sensitive to the inclusion of time fixed effects and addition of more recent data. When also considering stronger instruments, we obtain a pass-through estimate slightly above 1 , which contrasts sharply with Knight's zero pass-through result.

\section{Dynamic Results}

The static analyses summarized in Table 1 abstract from dynamics. Dynamics may be important in at least two respects. First, even if one is only interested in the contemporaneous passthrough effect, ignoring the persistence in both highway spending and grants can lead to biased estimates. Second, given the lengthy and complicated planning, bidding, and approval processes associated with infrastructure projects, the full response of state spending to grant shocks may well play out over several years. Hence, we turn to the dynamic specification in equation (1) and follow 
the IV approach of Ramey and Zubairy (2018) to estimate the full cumulative impulse response function, from the contemporaneous year $(h=0)$ to five years later $(h=5)$.

Before estimating equation (1), we first demonstrate the importance of the persistence of federal highway grants by estimating the impulse response of grants to an initial grant's shock using Jordà's (2005) local projection approach:

$$
\begin{aligned}
& F_{s, t+j}=\psi_{0} F_{s, t}+\sum_{\tau=1}^{3} \rho_{\tau}^{h} G_{s, t-\tau}+\sum_{\tau=1}^{3} \psi_{\tau}^{h} F_{s, t-\tau}+\gamma_{h}^{\prime} X_{s, t}+\delta_{t}^{h}+\alpha_{s}^{h}+\phi_{s}^{h} t+v_{s, t+h}, \\
& \quad \text { for } j \geq 0 .
\end{aligned}
$$

Here we treat grants in year $t$ as exogenous, conditional on lagged grants, lagged highway spending, the same set of conditioning variables used earlier, and time and state fixed effects. Equation (2) is similar to equation (1), but it replaces state highway spending with federal highway grants on the left-hand side and excludes leads of federal highway grants in the first term on the right-hand side (because they are now the dependent variables). Using this framework, we can estimate the IRF over time by stepping $j$ forward.

As shown in Figure 1, the estimated IRF shows that a $\$ 1$ increase in current grants is associated with increases in highway grants the next year and up to four years in the future. Overall, a $\$ 1$ grant shock today ultimately represents an increase of slightly more than $\$ 2$ in grants over a five-year period. As a result, ignoring this dynamic response could lead to an overestimation of the cumulative pass-through effect on highway spending from a grant shock today. The approach we take in equation (1) avoids this issue, since it also captures the cumulative increase in state highway spending triggered by the cumulative increase in federal highway grants, as the time horizon $j$ increases.

The key results of estimating equation (1) are shown in Table 2. Panel A provides the contemporaneous pass-through estimates. Panel B provides estimates of the cumulative passthrough as of five years beyond the initial grants shock. We focus on this six-year window $(\mathrm{h}=0$ to 5) given the evidence in Figure 1 that the boost to future highway grants after an initial shock lasts no longer than five years. The first column in each panel reports the results of estimating equation (1) but omitting lags of state highway spending and federal highway grants $\left(\rho_{\tau}^{h}=\psi_{\tau}^{h}=\right.$ $0)$, time fixed effects $\left(\delta_{t}^{h}=0\right)$, and state-specific trends $\left(\varphi_{s}^{h}=0\right)$. With these constraints, this specification when $h=0$ is identical to that underlying the last column of Table 1, when using 
apportionments as instruments. We focus here on results derived under this IV approach given the evidence from Table 1 that these instruments provide a much stronger first-stage fit.

Comparing the column (1) results in Panels A and B, we see that the cumulative passthrough estimate is even higher than the contemporaneous estimate. As of five years ahead, the cumulative pass-through estimate rises to 1.3 , compared to a contemporaneous estimate of 1.17 , and is highly statistically significant.

In the second column of Table 2, we provide a more general specification that includes three lags of state highway grants and of federal highway grants but still abstracts from statespecific trends. Adding these lags has little effect on the pass-through estimates, suggesting the results are robust to accounting for the persistence of spending and grants. In the third column, we increase the generality of our specification further by adding state-specific time trends. This addition does not lead to any meaningful change in the results. ${ }^{12}$

Finally, for completeness, we repeat the regressions underlying columns (2) and (3), i.e., with and without state-specific time trends, but now measuring the year $t$ grants shock simply with year $t$ grants. In other words, we treat current grants as exogenous and use it as the instrument for cumulative grants when $h>0$. When $h=0$ (Panel A), this is simply the OLS estimation of equation (1). As before, we find relatively high contemporaneous and cumulative pass-through, though a bit smaller than in columns (2) and (3). Still, the cumulative pass-through in this case remains essentially 1.

\section{Business Cycles and Savings}

In this section, we examine the sensitivity of our results to the national business cycles and state savings. States may face increased pressure to divert federal highway grants to other spending needs that are perceived as more urgent during recessions or when they have little or no savings. The fact that states generally are only permitted to borrow for infrastructure projects and not for other spending needs makes this possibility especially likely.

The first column of Table 3 shows the results when we include a term interacting federal highway grants with a national recession indicator based on NBER business cycle dating in equation (2). As before, we use highway grant apportionments as an instrument. We find that the

\footnotetext{
${ }^{12}$ Note that the results in Table 2 are robust to the addition of state population as an additional control, likely because the vast majority of variation in state population is absorbed by state and year fixed effects.
} 
degree of contemporaneous or cumulative pass-through is insensitive to whether states receive highway grants during an expansion or a recession, and both estimates remain above 1 .

In contrast, we find some evidence that a state's amount of savings affects the estimated degree of pass-through. Savings are measured as the sum of end-of-fiscal-year general fund balances plus any separate rainy day fund balances, using data from the National Association of State Budget Officers. We construct an indicator for whether savings in a given state-year observation is above the sample mean and interact that indicator with highway grants in equation (2).

The first column of Table 3 shows that, while savings do not play a role for contemporaneous pass-through, cumulative pass-through is higher when savings are high. In this case, we find that high savings boost the cumulative pass-through estimate by roughly 15 percent. While we do not formally provide a mechanism that could account for this result, one possibility is that rent-seeking efforts, which previously have been found to help explain high pass-through estimates (Leduc and Wilson 2017), are more intense when states have low savings and are under more pressure to divert federal funding to uses other than those intended.

\section{Conclusion}

We revisited and extended Knight's (2002) influential finding that federal highway grants to states perfectly crowd out state highway spending, implying zero pass-through. We showed that this result is entirely reversed by including time fixed effects and by extending the data sample to the late 2010s. In this case, we consistently found that the contemporaneous pass-through estimate is roughly 1 . Moreover, we showed that taking dynamic effects into account pushes this estimate up further to around 1.3, suggesting that federal highway grants crowd $i n$ state highway spending. Thus, federal highway grants lead states to spend more on highways than previously thought, which would tend to boost the effects of federal infrastructure spending on highways.

\section{References}

Baicker, Katherine (2001). "Government decision-making and the incidence of federal mandates." Journal of Public Economics 82 (2): 147-94.

Card, David, and A. Abigail Payne (2002). "School finance reform, the distribution of school spending, and the distribution of student test scores." Journal of Public Economics 83 (1): 4982. 
Congressional Budget Office (2016). "The Macroeconomic and Budgetary Effects of Federal Investment."

Congressional Budget Office (2021). "H.R. 748, CARES Act, Public Law 116-136."

Duggan, Mark (2000). "Hospital Ownership and Public Medical Spending," Quarterly Journal of Economics 115(4), pp. 345-386.

Federal Highway Administration. 2007. "Financing Federal-Aid Highways,” FHWA-PL-07-017.

Federal Highway Administration. 2009. "Apportionment of Highway Infrastructure Investment Funds Pursuant to the American Recovery and Reinvestment Act of 2009, Public Law Number 111-5," FHWA Notice.

Gordon, Nora (2004). "Do federal grants boost school spending? Evidence from Title I." Journal of Public Economics 88 (9-10): 1771-92.

Hines, James R. Jr. and Richard H. Thaler (1995). “Anomalies: The Flypaper Effect,” Journal of Economic Perspectives 9: pp. 217-226.

Hoxby, Caroline M. (2001). “All School Finance Equalizations Are Not Created Equal.” Quarterly Journal of Economics 116 (4): 1189-1231.

Inman, Robert P. (2008). “The Flypaper Effect.” NBER Working Paper 14579.

Jordà, Oscar (2005). "Estimation and Inference of Impulse Responses by Local Projections," American Economic Review 95(1): pp. 161-182.

Knight, Brian (2002). "Endogenous Federal Grants and Crowd-out of State Government Spending: Theory and Evidence from the Federal Highway Program." American Economic Review, 92(1): pp. 71-92.

Leduc, Sylvain and Daniel J. Wilson (2013). "Roads to Prosperity or Bridges to Nowhere: Theory and Evidence on the Impact of Public Infrastructure Investment." NBER Macroeconomic Annual 2012, Vol. 27, Daron Acemoglu, Jonathan Parker, and Michael Woodford, editors, pp. 89-142.

Leduc, Sylvain, and Daniel Wilson. (2017). "Are State Governments Roadblocks to Federal Stimulus? Evidence on the Flypaper Effect of Highway Grants in the 2009 Recovery Act." American Economic Journal: Economic Policy 9(2), pp. 253-292.

https://www.aeaweb.org/articles?id=10.1257/pol.20140371

Lutz, Byron (2010). "Taxation with Representation: Intergovernmental Grants in a Plebiscite Democracy." Review of Economics and Statistics 92 (2): 316-32. 
Ramey, Valerie A and Sarah Zubairy (2018). "Government Spending Multipliers in Good Times and in Bad: Evidence from US Historical Data," Journal of Political Economy 126(2), pp. 850899.

Singhal, Monica (2008). "Special interest groups and the allocation of public funds," Journal of Public Economics 92: pp. 548-564. 


\section{Appendix I. Data}

This section describes the data on state government spending, regular federal-aid highway grants, ARRA highway grants, the instruments, and the conditioning variables used to estimate the regressions discussed earlier.

\section{A. State Government Spending}

Data on highway-related expenditures and total general-fund expenditures by each state government come from the Census Bureau's Survey of State Government Finances (SGF). These data are available from 1977 to [2011]. We measure highway expenditures as the sum of regular and toll highway expenditures on (1) current operations, (2) construction outlays, (3) other capital outlays, and (4) transfers to local governments for roads. The SGF defines highway expenditures as expenditures on " $[\mathrm{m}]$ aintenance, operation, repair, and construction of highways, streets, roads, alleys, sidewalks, bridges, tunnels, ferry boats, viaducts, and related non-toll [and toll] structures." For each state, data in the SGF are reported for that state's fiscal year. All but four states have fiscal years ending June 30 of the named year (e.g., FY2012 begins July 1, 2011 and ends June 30, 2012). The other four states - Alabama, Michigan, New York, and Texas - have fiscal years ending September 30 of the named year.

\section{B. Regular (Non-ARRA) Federal-Aid Highway Grants}

When referring to federal aid, the term "grants" typically denotes the amount of intergovernmental transfers from the federal government to other levels of government. Yet there are at least three distinct concepts, or measures, of grants that differ importantly in their timing: Apportionments, Obligations, and Outlays. These concepts are described briefly below; see FHWA (2007) for details.

"Apportionments" are the amounts of congressionally authorized federal funding that each state is eligible to receive for reimbursement of FHWA-approved highway costs. For federal highway grants, each program within the FAHP apportions these authorized national totals to states based on a statutory apportionment formula, as discussed earlier. Each year, the annual apportionments for each program are announced at the start of the federal fiscal year (October 1). At that time, no actual funds are transferred from the federal government to states. Rather, these announcements inform states of the funding they are eligible to receive as reimbursement for 
expenditures on FHWA-approved projects. After states are informed of their apportionments, they then are able to obligate those prospective funds to specific FHWA-approved projects. For regular (non-ARRA) highway grants, states typically have up to four years to obligate apportioned funds. In contrast, an important feature of ARRA highway grants was the requirement that states obligate funds within 18 months of apportionment - that is, by September 30, 2010, 18 months from March 2, 2009, the date on which ARRA highway grant apportionments were announced (see FHWA (2009)). As mentioned earlier, this provision was included in the ARRA to provide incentives to states to start highway projects quickly, while they could provide the greatest countercyclical stimulus, rather than over the usual several-year process. We provide evidence suggesting that indeed the lag between grant apportionments and obligations, and in turn outlays, was much shorter for ARRA grants than for regular, non-ARRA grants.

The sum of state government obligations within each state and year are the FHWA's "obligations" for that state-year. These obligations are effectively promises by the federal government to reimburse the states for future costs. Still, no actual funds are transferred at this time. Once projects commence and costs are incurred, payments are made from the state government to the contractors or local government agencies engaged in the work and the federal

government transfers funds to the state government's general fund. These federal reimbursements are referred to as FHWA "outlays."

Data on apportionments, obligations, and outlays are available from the Office of Highway Policy Information's annual Highway Statistic Series publications (Tables FA-4, FA-4B, and FA3, respectively). For 2009 onward, the reported totals for obligations in these statistics include FHWA obligations of ARRA funds, while the totals for apportionments and outlays do not. Data on ARRA FHWA apportionments, obligations, and outlays are available separately, allowing us to measure these three variables both gross and net of ARRA grants.

\section{ARRA Highway Grants}

Data on ARRA highway grant apportionments come from the March 2, 2009 FHWA Notice, "Apportionment of Highway Infrastructure Investment Funds Pursuant to the American Recovery and Reinvestment Act of 2009, Public Law Number 111-5” (FHWA 2009). Data on ARRA obligations and outlays by state are available from recovery.gov, the website set up by the federal government to provide information to the public about how ARRA funds are being spent. 
For each government department, the website provides weekly Financial and Activity Reports containing the cumulative-to-date amounts of awards and outlays for each specific grant, loan, or contract by state and subagency (such as the FHWA). From the Department of Transportation's Financial and Activity Reports, we computed the sum of all FHWA-issued grants - measured by both obligations and outlays - by state over the course of each federal fiscal year (2009-2011). (FHWA grants are identified by the TAFS code 69-0504.)

In our cross-sectional regressions, which focus on the effect of ARRA grants on state government highway spending in 2010, we consider three alternative measures of ARRA highway grants. The first is ARRA highway apportionments to the state (i.e., the announcements of ARRA highway grant apportionments on March 2, 2009). The second is the ARRA highway obligations through the end of the federal fiscal year 2010 (September 30,2010). This variable turns out to be nearly equivalent to ARRA highway apportionments because of the ARRA requirement that apportioned funds be obligated within 18 months of the apportionment date - that is, by September 2, 2010. The third measure is ARRA highway outlays through the end of (federal) fiscal year 2010. In some regressions, we look at state government highway spending in 2011; for those regressions, we use ARRA highway apportionments, obligations, and outlays through fiscal year 2011, though ARRA apportionments were zero after 2009 and obligations were very close to zero after 2010 .

It is worth noting that there is a one-quarter misalignment between our data on state government spending and federal grants. Four states (Alabama, Michigan, New York, and Texas) have the same fiscal year as the federal government, which ends September 30 of the calendar year. But the other 43 states in our sample have fiscal years that end one quarter earlier. This misalignment can be thought of as adding measurement error to the true dependent variable, state government spending within the federal fiscal year. As long as this measurement error is uncorrelated with highway grants (for ordinary least squares (OLS) regressions) or with the instruments (for IV regressions), it will not cause any bias and will be reflected in the size of the standard errors.

\section{Instruments}

Data on FHWA apportionment formula factors comes from the Office of Highway Policy Information's annual Highway Statistic Series publications, Table FA-4E. The number of miles in 
each state of the 1944 NIHC proposed national highway system can be found in Table 1 of the 1944 NIHC Report to Congress (NIHC 1944, pp. 8-9). The Congressional power instruments used in some specifications are described in Stewart and Woon (2012) and were pulled from Charles Stewart's website: http://web.mit.edu/17.251/www/data_page.html\#2 (accessed on 10/28/2021). These data cover through the $115^{\text {th }}$ U.S. Congress, which governed during 2017 and 2018. As of the time of this writing, these data are not available beyond 2018.

\section{E. Conditioning Variables}

Our baseline specification includes several conditioning variables that could potentially affect or predict post-ARRA state highway spending while also being correlated with ARRA highway grants or the instruments. We include the 2008-2010 change in state income per capita (in 1997 dollars), using data from the Bureau of Economic Analysis. We include the 2008-2010 change in three variables meant to capture the state residents' preferences regarding public spending. These variables were also included in Knight's (2002) study of the flypaper effect of federal highway grants. The first is an indicator variable for whether the governor is a Democrat (1) or Republican (0). The other two are the share of legislators in the state's House of Representatives that are Democrats and share of legislators in the state's Senate that are Democrats. The data for these political variables come from the Council of State Governments.

In various robustness checks presented later in the paper, we also condition on a lagged dependent variable (2006 to 2008 change in highway spending), the 10-year trend in highway spending leading up to the Recovery Act, the pre-recession run-up in house prices, the 2008 level of the index of leading economic indicators (from the Federal Reserve Bank of Philadelphia), the 2006 to 2008 change in the index of leading indicators, and the 2008 levels of the three political variables described above. 
Table 1: Flypaper Effect of FHWA Grants, Various Specifications

\begin{tabular}{|c|c|c|c|c|c|c|}
\hline & $\begin{array}{c}(1) \\
\text { Knight Replication }\end{array}$ & $\begin{array}{c}(2) \\
\text { Our Data }\end{array}$ & $\begin{array}{c}(3) \\
\text { GSP Deflation }\end{array}$ & $\begin{array}{c}(4) \\
+ \text { Year FEs }\end{array}$ & $\begin{array}{c}\text { (5) } \\
\text { +Recent Years }\end{array}$ & $\begin{array}{c}(6) \\
\text { Apportionments IV }\end{array}$ \\
\hline Predicted Highway Grants & $\begin{array}{c}0.1214 \\
(0.4199)\end{array}$ & $\begin{array}{c}0.0841 \\
(0.2905)\end{array}$ & $\begin{array}{c}0.2990 \\
(0.2687)\end{array}$ & $\begin{array}{l}0.5353^{*} \\
(0.2820)\end{array}$ & $\begin{array}{l}1.6132^{* * *} \\
(0.2775)\end{array}$ & $\begin{array}{l}1.1624^{* * *} \\
(0.1030)\end{array}$ \\
\hline Income Per Capita & $\begin{array}{c}0.0100^{* * *} \\
(0.0013)\end{array}$ & $\begin{array}{l}0.0104^{* * *} \\
(0.0010)\end{array}$ & $\begin{array}{c}0.0095^{* * *} \\
(0.0009)\end{array}$ & $\begin{array}{c}0.0053^{* * *} \\
(0.0020)\end{array}$ & $\begin{array}{l}0.0130^{* * *} \\
(0.0011)\end{array}$ & $\begin{array}{c}0.0127^{* * *} \\
(0.0010)\end{array}$ \\
\hline Population & $\begin{array}{l}-0.0006 \\
(0.0035)\end{array}$ & $\begin{array}{l}-0.0003 \\
(0.0034)\end{array}$ & $\begin{array}{l}-0.0008 \\
(0.0033)\end{array}$ & $\begin{array}{l}-0.0028 \\
(0.0032)\end{array}$ & $\begin{array}{c}0.0029 \\
(0.0019)\end{array}$ & $\begin{array}{c}0.0020 \\
(0.0015)\end{array}$ \\
\hline Drivers Per Capita & $\begin{array}{c}-116.6749^{*} \\
(64.3122)\end{array}$ & $\begin{array}{c}-104.9117^{*} \\
(58.3451)\end{array}$ & $\begin{array}{l}-66.0286 \\
(54.3587)\end{array}$ & $\begin{array}{l}-71.1605 \\
(50.3925)\end{array}$ & $\begin{array}{l}-2.0948 \\
(47.4800)\end{array}$ & $\begin{array}{c}14.3235 \\
(44.1458)\end{array}$ \\
\hline Vehicles Per Capita & $\begin{array}{l}-26.2207 \\
(34.6197)\end{array}$ & $\begin{array}{c}10.3888 \\
(32.2670)\end{array}$ & $\begin{array}{c}45.3936 \\
(32.1099)\end{array}$ & $\begin{array}{c}7.0553 \\
(33.1871)\end{array}$ & $\begin{array}{c}-64.4342^{* *} \\
(31.5127)\end{array}$ & $\begin{array}{l}-33.2363 \\
(20.8264)\end{array}$ \\
\hline Governor Democrat & $\begin{array}{l}6.1768^{*} \\
(3.5188)\end{array}$ & $\begin{array}{l}-5.2855 \\
(3.3505)\end{array}$ & $\begin{array}{l}-3.4712 \\
(3.2943)\end{array}$ & $\begin{array}{l}-4.9120 \\
(3.2530)\end{array}$ & $\begin{array}{l}-4.5960 \\
(3.3558)\end{array}$ & $\begin{array}{l}-3.8525 \\
(3.0922)\end{array}$ \\
\hline State House Democrats & $\begin{array}{c}24.2678 \\
(28.9005)\end{array}$ & $\begin{array}{c}7.6299 \\
(26.3871)\end{array}$ & $\begin{array}{c}8.1943 \\
(25.3326)\end{array}$ & $\begin{array}{c}-8.3379 \\
(25.4747)\end{array}$ & $\begin{array}{l}-14.6242 \\
(25.2367)\end{array}$ & $\begin{array}{l}-16.8272 \\
(23.9786)\end{array}$ \\
\hline State Senate Democrats & $\begin{array}{c}28.9344 \\
(24.1295)\end{array}$ & $\begin{array}{c}65.8919^{* * *} \\
(22.3080)\end{array}$ & $\begin{array}{c}63.0220^{* * *} \\
(21.3138)\end{array}$ & $\begin{array}{c}57.1440^{* * *} \\
(20.3026)\end{array}$ & $\begin{array}{c}-4.7473 \\
(22.9845)\end{array}$ & $\begin{array}{l}-17.3661 \\
(21.3081)\end{array}$ \\
\hline $\mathrm{R}^{2}$ & 0.181 & 0.262 & 0.331 & 0.237 & 0.193 & 0.244 \\
\hline First-stage F-stat & 2.642 & 6.475 & 6.421 & 5.482 & 10.866 & 140.697 \\
\hline Instrument Type & Political & Political & Political & Political & Political & Apportionments \\
\hline N Obs. & 705 & 705 & 705 & 705 & 1691 & 1737 \\
\hline State Fixed Effects & Yes & Yes & Yes & Yes & Yes & Yes \\
\hline Year Fixed Effects & No & No & No & Yes & Yes & Yes \\
\hline First Data Year & 1983 & 1983 & 1983 & 1983 & 1983 & 1983 \\
\hline Last Data Year & 1997 & 1997 & 1997 & 1997 & 2018 & 2019 \\
\hline
\end{tabular}

Standard errors in parentheses

${ }^{*} p<0.10,{ }^{* *} p<0.05,{ }^{* * *} p<0.01$ 
Table 2: Pass-Through Effect of FHWA Highway Grants on State Highway Spending

Panel A. Contemporaneous Effect

\begin{tabular}{|c|c|c|c|c|c|}
\hline & $\begin{array}{c}(1) \\
\text { Apportionments IV }\end{array}$ & $\begin{aligned} & (2) \\
+ & \operatorname{Lags}\end{aligned}$ & $\begin{array}{c}(3) \\
+ \text { Trends }\end{array}$ & $\begin{array}{c}(4) \\
\text { Exog.-No Trends }\end{array}$ & $\begin{array}{c}(5) \\
\text { Exog.-Trends }\end{array}$ \\
\hline Highway Grants & $\begin{array}{c}1.1624^{* * *} \\
(0.1030)\end{array}$ & $\begin{array}{l}1.0375^{* * *} \\
(0.2007)\end{array}$ & $\begin{array}{c}1.1800^{* * *} \\
(0.3178)\end{array}$ & $\begin{array}{c}0.6313^{* * *} \\
(0.0453)\end{array}$ & $\begin{array}{c}0.6354^{* * *} \\
(0.0463)\end{array}$ \\
\hline N Obs. & 1737 & 1737 & 1737 & 1737 & 1737 \\
\hline $\mathrm{R}^{2}$ & 0.244 & 0.670 & 0.463 & 0.685 & 0.506 \\
\hline First-stage F-stat & 140.697 & 23.065 & 9.395 & . & . \\
\hline Instrument Type & Apportionments & Apportionments & Apportionments & Current Grants & Current Grants \\
\hline State Fixed Effects & Yes & Yes & Yes & Yes & Yes \\
\hline Year Fixed Effects & Yes & Yes & Yes & Yes & Yes \\
\hline State-Specific Trends & No & No & Yes & No & Yes \\
\hline First Data Year & 1983 & 1983 & 1983 & 1983 & 1983 \\
\hline Last Data Year & 2019 & 2019 & 2019 & 2019 & 2019 \\
\hline
\end{tabular}

Panel B. Five-Year Cumulative Effect

\begin{tabular}{lccccc}
\hline \hline & $(1)$ & $(2)$ & $(3)$ & $(4)$ & $(5)$ \\
& + Lags & + Trends & Exog.-No Trends & Exog.-Trends \\
\hline Highway Grants & $1.3340^{* * *}$ & $1.2380^{* * *}$ & $1.2452^{* * *}$ & $1.0519^{* * *}$ & $1.0166^{* * *}$ \\
& $(0.0938)$ & $(0.1285)$ & $(0.2340)$ & $(0.1120)$ & $(0.1297)$ \\
\hline N Obs. & 1504 & 1504 & 1504 & 1504 & 1504 \\
$\mathrm{R}^{2}$ & 0.341 & 0.511 & 0.267 & 0.517 & 0.281 \\
First-stage F-stat & 219.394 & 95.335 & 26.144 & 540.772 & 401.309 \\
Instrument Type & Apportionments & Apportionments & Apportionments & Current Grants & Current Grants \\
State Fixed Effects & Yes & Yes & Yes & Yes & Yes \\
Year Fixed Effects & Yes & Yes & Yes & Yes & Yes \\
State-Specific Trends & No & No & Yes & No & Yes \\
First Data Year & 1983 & 1983 & 1983 & 1983 & 1983 \\
Last Data Year & 2019 & 2019 & 2019 & 2019 & 2019 \\
\hline \hline
\end{tabular}

Standard errors in parentheses

${ }^{*} p<0.10,{ }^{* *} p<0.05,{ }^{* * *} p<0.01$

Notes: All regressions also include three lags of the dependent variable, three lags of federal highway grants, and the following control variables: Income p.c., Population, Drivers p.c., Vehicles p.c., Democratic Governor Dummy, Democrats \% of State House, Democrats \% of State Senate. 
Table 3: Heterogeneous Pass-Through Effect By Business Cycle and State Savings

Panel A. Contemporaneous Effect

\begin{tabular}{lcc}
\hline \hline & $\begin{array}{c}(1) \\
\text { Recession Int. }\end{array}$ & $\begin{array}{c}(2) \\
\text { Savings Int. }\end{array}$ \\
\hline Highway Grants & $1.1556^{* * *}$ & $1.1699^{* * *}$ \\
& $(0.3028)$ & $(0.2932)$ \\
Highway Grants* Recession & 0.0108 & \\
& $(0.0594)$ & \\
Highway Grants*High Savings & & \\
& & $0.1185^{* *}$ \\
\hline N Obs. & 1737 & $(0.0469)$ \\
$\mathrm{R}^{2}$ & 0.467 & 1737 \\
First-stage F-stat & 5.102 & 0.460 \\
Instrument Type & Apportionments & Apportionments \\
State Fixed Effects & Yes & Yes \\
Year Fixed Effects & Yes & Yes \\
State-Specific Trends & Yes & Yes \\
First Data Year & 1983 & 1983 \\
Last Data Year & 2019 & 2019 \\
\hline \hline
\end{tabular}

Panel B. Five-Year Cumulative Effect

\begin{tabular}{lcc}
\hline \hline & $(1)$ & $(2)$ \\
& Recession Int. & Savings Int. \\
\hline Highway Grants & $\left(0.1342^{* * *}\right.$ & $1.2469^{* * *}$ \\
& & $(0.2335)$ \\
Highway Grants* Recession & 0.0602 & \\
& $(0.0406)$ & \\
Highway Grants*High Savings & & \\
& & $0.1536^{* * *}$ \\
N Obs. & 1504 & $(0.0420)$ \\
$\mathrm{R}^{2}$ & 0.278 & 1504 \\
First-stage F-stat & 13.787 & 0.266 \\
Instrument Type & Apportionments & Apportionments \\
State Fixed Effects & Yes & Yes \\
Year Fixed Effects & Yes & Yes \\
State-Specific Trends & Yes & Yes \\
First Data Year & 1983 & 1983 \\
Last Data Year & 2019 & 2019 \\
\hline \hline Standard errors in parentheses & & \\
$* p<0.10, * *$ & \\
& & \\
& &
\end{tabular}

Notes: All regressions also include three lags of the dependent variable, three lags of federal highway grants, and the following control variables: Income p.c., Population, Drivers p.c., Vehicles p.c., Democratic Governor Dummy, Democrats \% of State House, Democrats \% of State Senate. 
Figure 1: Dynamic Response of Grants to a Grants Shock

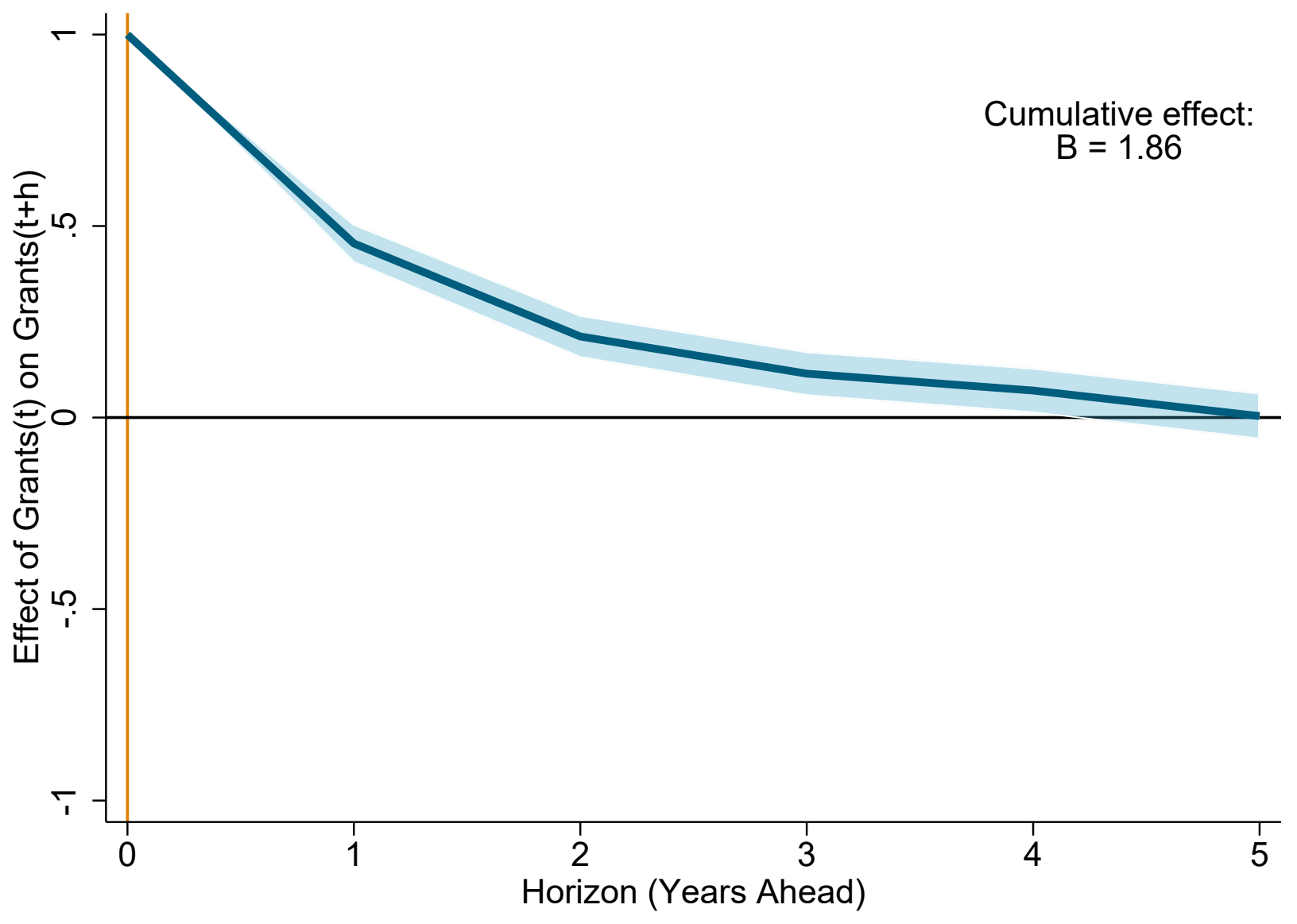

